\title{
Expression of Stem Cell Marker Nestin and MicroRNA-21 in Meningiomas
}

\author{
Menenjiyomlarda Kök Hücre Işareti Nestin ve MicroRNA-21 \\ Ekspresyonu
}

\author{
Vasiliki GALANI ${ }^{1}$, George A ALEXIOU ${ }^{2}$, Georgios MILIARAS², Efthymios DIMITRIADIS ${ }^{3}$, \\ Elena TRIANTAFYLLOU ${ }^{1}$, Aggeliki GALANII ${ }^{4}$, Anna GOUSSIA ${ }^{5}$, Panagiotis KANAVAROS ${ }^{1}$, \\ Theoni TRANGAS ${ }^{6}$ \\ ${ }^{1}$ University of Ioannina, Faculty of Medicine, Department of Anatomy-Histology-Embryology, Epirus, Greece \\ 2 University Hospital of Ioannina, Department of Neurosurgery, Epirus, Greece \\ 3 "St. Savvas" Anticancer Hospital, Department of Genetics, Athens, Greece \\ ${ }^{4}$ University of Patras, Department of Environmental and Natural Resources Management, Patra, Greece \\ 5 University of Ioannina, Faculty of Medicine, Department of Pathology, Epirus, Greece \\ ${ }^{6}$ University of Ioannina, Department of Biological Applications and Technologies, Epirus, Greece
}

Corresponding Author: Alexiou GEORGE / E-mail: alexiougrg@yahoo.gr, alexiougr@gmail.com

\section{ABSTRACT}

AIM: Meningiomas are one of the most common benign intracranial tumors, making up nearly one third of all primary intracranial tumors. The majority of meningiomas have benign histological features and total resection is associated with favourable prognosis. Atypical and malignant meningiomas are associated with increased risk of recurrence. In the present study we set out to investigate the role of nestin mRNA levels and miR-21 in meningiomas.

MATERIAL and METHODS: We studied 17 patients with meningiomas that were treated surgically in our institute. Clinical variables that were analyzed were age, sex and histology. The expression of stem cell marker nestin mRNA levels and miR-21 was investigated in tissue samples by qRT-PCR.

RESULTS: Considerable levels of both miR-21 and nestin mRNA were found. Atypical and anaplastic meningiomas had higher expression of both miR-21 and nestin compared to benign tumors. Furthermore, a trend towards a positive correlation between miR-21 and nestin mRNA levels was also found.

CONCLUSION: Increased miR-21 and nestin mRNA levels were found in anaplastic meningiomas, in which recurrence is common, and the role of miR-21 and Nestin in meningiomas therefore warrants further investigation.

KEYWORDS: miR-21, Nestin, Meningioma, Recurrence

Öz

AMAÇ: Menenjiyomlar en sık görülen benign intrakraniyal tümörlerdendir ve tüm primer intrakraniyal tümörlerin neredeyse üçte birini oluştururlar. Menenjiyomların çoğunda benign histolojik özellikler mevcuttur ve total rezeksiyon olumlu bir prognozla ilişkilidir. Atipik ve malign menenjiyomlar artmış nüks riskiyle ilişkilidir. Çalışmada, menenjiyomlarda nestin mRNA seviyeleri ve miR-21 rolünü incelemeyi amaçladık.

YÖNTEM ve GEREÇLER: Enstitümüzde cerrahi tedavi gören 17 menenjiyom hastasını inceledik. Analiz edilen klinik değişkenler yaş, cinsiyet ve histolojiydi. Kök hücre işareti nestin mRNA seviyeleri ve miR-21 ekspresyonu doku örneklerinde qRT-PCR ile incelendi.

BULGULAR: Hem miR-21 hem nestin mRNA düzeyleri önemli bulundu. Atipik ve anaplastik menenjiyomlarda benign tümörlere göre hem miR-21 hem nestin ekspresyonu daha yüksekti. Ayrıca miR-21 ve nestin mRNA seviyeleri arasında pozitif korelasyon açısından bir eğilim de bulundu.

SONUÇ: Nüksün sık görüldüğü anaplastik menenjiyomlarda artmış miR-21 ve nestin mRNA seviyeleri bulundu. Menenjiyomlarda miR-21 ve nestin rolünün daha ileri incelenmesi gerekir.

ANAHTAR SÖZCÜKLER: miR-21, Nestin, Menenjiyom, Nüks 


\section{INTRODUCTION}

Meningiomas are one of the most common benign intracranial tumors, making up nearly one third of all primary intracranial tumors. $(2,23)$. Intracranial meningiomas are more common in women than men and usually occur in patients aged 5060 years. About $2-3 \%$ of the population has been reported to have an incidental meningioma (18). Even if the majority of meningiomas have benign histological features and complete removal is associated with good prognosis, atypical and malignant meningiomas constitute nearly $6 \%$ and $2 \%$ of cases, respectively, and have been linked with increased risk of recurrence $(1,13,14)$.

Nestin was first described as a neuronal stem cell marker and constitutes a class VI intermediate filament protein $(9,19)$. Nestin has been found to have higher expression levels in malignant gliomas compared to low-grade tumors (11). MIRN21 (miR-21) was among the first microRNAs reported. MiR-21 has been implicated in several malignant tumors and most of its targets are tumor suppressors (12). In the present study we set out to investigate the role of nestin mRNA levels and miR-21 in meningiomas.

\section{MATERIAL and METHODS}

We studied 17 patients with meningiomas that were treated surgically in our institute. Clinical variables that were analyzed were age, sex and meningioma's histology. The expression of stem cell marker nestin mRNA levels and miR-21 was investigated in tissue samples.

\section{Tissue Collection, DNA, RNA Isolation}

Tissue samples were collected and stored in $-80^{\circ} \mathrm{C}$. Total RNA was isolated using the miRNeasy extraction kit (Qiagen, $\mathrm{GmbH}$, Germany) according to the manufacturer's instructions.

\section{Quantitative RT-PCR}

Quantitative RT-PCR was used to access the expression of the microRNA miR-21 and the nestin (NES) gene. The levels of the RUNU1 and $\beta 2$ microglobulin (B2M) transcripts were also measured as reference genes. Total RNAs were reverse transcribed in a $20 \mu \mathrm{l}$ reaction using the miScript Reverse Transcription Kit (Qiagen). The CDNA was subjected to real time quantitative PCR using the QuantiTect SYBR Green kit (Qiagen) for both miR-21 (MS00009086) and RNU1A (MS00013986) microRNAs using primer sets obtained from Qiagen and the recommended PCR conditions. For NES, and B2M gene transcripts, SYBR Green qPCR was applied using the primers and PCR conditions described in Table I. All PCR amplifications were performed in $20 \mu$ reaction, containing $1 X$ Platinum SYBR Green Quantitative PCR Super mix (Invitrogen, Carlsbad, California, USA), and 5 pmol of each primer. The qPCR results for all the genes were calculated using the relative quantification method with the use of RelQuant software (Roche Molecular Biochemicals, Mannheim, Germany) and expressed as the ratio of target gene/reference gene.

\section{Statistical Analysis}

Pearson's correlation coefficient was used to correlate between continuous variables. To investigate whether tumor grade correlate's with nestin and miR-21 expression we used Mann-Whitney test. A two-sided P value $<0.05$ was considered statistically significant.

\section{RESULTS}

There were 5 males and 12 females (mean age 60.3 \pm 16.3 , range 23 to 80 years). Two meningiomas were anaplastic (Grade III, WHO), four were atypical (Grade II, WHO) and the remaining eleven meningiomas were benign (Grade I, WHO). The mean miR-21 relative expression value was 14.18 \pm 44 .6. Anaplastic and atypical meningiomas had higher miR-21 expression compared to benign tumors but the difference was not statistical significant ( 3.01 vs. $0.058, p=0.3$ and 1.79 vs. $0.058, p=0.9$ respectively). The mean nestin relative $m R N A$ level was $0.05 \pm 0.08$. Anaplastic and atypical meningiomas had higher nestin mRNA levels compared to benign tumors but the difference was not statistical significant (0.013 vs. $0.0094, p=0.5$ and 0.014 vs. $0.0094, p=0.9$ respectively). Using Pearson's correlation coefficients a trend was found but not a significant correlation between miR-21 and nestin mRNA levels $(r=0.425, p=0.1)$.

\section{DISCUSSION}

The present study showed considerable expression of both miR-21 and nestin mRNA levels in meningiomas. Atypical and anaplastic meningiomas had higher expression of both miR-21 and nestin compared to benign tumors. Furthermore, a trend towards a positive correlation between miR-21 and nestin mRNA levels was also found. To the best of our knowledge to date no previous study has evaluated the expression of miR-21 in meningiomas.

Meningiomas constitute in the majority of cases benign tumors, however their growth potential varies. Some remain unaltered in size for a long period, while others tend to grow fast (10). Surgical resection remains the treatment mainstay $(1,24)$. In benign meningiomas total excision is associated with favorable prognosis, provided that complete tumor excision has been performed. Nevertheless, a significant risk of recurrence has been reported, even after complete meningioma resection with excision of the dura and affected bone (16). Thus, even among benign meningiomas prognosis

Table I: Primer Sequence and PCR Conditions

\begin{tabular}{|l|l|c} 
primer & sequence & Tm \\
\hline Nestin F & cag cgt tgc aac aga ggt tgg & \\
Nestin R & tgg cac agg tgt ctc aac ggt ag & $63^{\circ} \mathrm{C}$ \\
B2MF & atc ttc aaa cct cca tga tg & \\
B2MR & acc ccc act gaa aaa gat ga & $54^{\circ} \mathrm{C}$ \\
Musashi F & tgt cac gtt tga gag cga gga cat & \\
Musashi R & Cat tgg tga agg ctg tgg caa tca &
\end{tabular}


may be different $(8,23)$. On the contrary, recurrence is very common in malignant meningiomas, even after total resection $(13,21)$. Thus, assessment of tumor's biological behavior could serve as an important prognostic factor.

MicroRNAs (miRNAs) are a recently discovered family of genes encoding small RNA molecules that can affect gene expression (5). A potential role for miRNAs in malignancy has been suggested. The miR-21 has been reported to be overexpressed in several tumors and may be a promising clinical biomarker and for possible therapeutic targeting (6). Markedly elevated miR-21 levels have been found in glioblastoma (7). Recently, Hermansen et al. reported that miR-21 is located in both tumor cells and tumor blood vessels and that its level in the tumor cell has unfavorable prognostic value in gliomas (7). To the best of our knowledge no previous study has evaluated miR-21 in meningiomas. Herewith, we found that atypical and malignant meningioma had higher miR-21 levels than benign meningioma. Recently, Zhi et al. reported that downregulation of $\mathrm{miR}-29 c-3 p$ and $m i R-219-5 p$ was associated with advanced clinical stages of meningioma. Apart from that, increased expression of miR-190a and low expression of miR-29c-3p and miR-219-5p was associated with an increased recurrence risk in meningioma patients (25). miR-335 has been also found elevated in meningiomas. Shi et al. reported that miR-335 plays a pivotal role in the proliferation of meningioma cells, since it is involved in the Rb1 signaling pathway (20).

Nestin is a class six intermediate filament protein that is expressed, apart from central nervous system (CNS) development, also in CNS tumors (22). Nestin is expressed in stem cells of the subventricular zone and to a lower degree in the choroid plexus of the normal brain (17). Abundant immunopositivity for nestin has been reported in malignant CNS tumors (3). Pilocytic astrocytomas demonstrated low nestin expression (3) Recently, Arai et al. found nestin a useful marker for diagnosis of high-grade gliomas and schwannomas. Furthermore, nestin expression was related to poor prognosis in high-grade gliomas (4). In ependymoma, nestin positivity was found to be an independent marker for short progression-free survival and overall survival (15). To the best of our knowledge no previous study assessed the nestin expression in various meningioma grades. The results showed that atypical and anaplastic meningiomas had higher expression of nestin compared to benign tumors.

The present study has several limitations. The first is the limited number of patients that were evaluated. Furthermore, only qRT-PCR was performed in tumor tissue. Nevertheless, increased miR-21 and nestin mRNA levels were found in anaplastic meningiomas, in which recurrence is common, and thus they might have a prognostic significance. The role of miR-21 and nestin in meningiomas thus warrants further investigation.

\section{REFERENCES}

1. Alexiou GA, Gogou P, Markoula S, Kyritsis AP: Management of meningiomas. Clin Neurol Neurosurg 112:177-182, 2010

2. Alexiou GA, Markoula S, Gogou P, Kyritsis AP: Genetic and molecular alterations in meningiomas. Clin Neurol Neurosurg 113:261-267, 2011

3. Almqvist PM, Mah R, Lendahl U, Jacobsson B, Hendson G: Immunohistochemical detection of nestin in pediatric brain tumors. J Histochem Cytochem 50:147-158, 2002

4. Arai $\mathrm{H}$, Ikota H, Sugawara K, Nobusawa S, Hirato J, Nakazato Y: Nestin expression in brain tumors: Its utility for pathological diagnosis and correlation with the prognosis of high-grade gliomas. Brain Tumor Pathol 29:160-167, 2012

5. Bartel DP: MicroRNAs: Genomics, biogenesis, mechanism, and function. Cell 116:281-297, 2004

6. Chan JA, Krichevsky AM, Kosik KS: MicroRNA-21 is an antiapoptotic factor in human glioblastoma cells. Cancer Res 65:6029-6033, 2005

7. Hermansen SK, Dahlrot RH, Nielsen BS, Hansen S, Kristensen BW: MiR-21 expression in the tumor cell compartment holds unfavorable prognostic value in gliomas. J Neurooncol 111:71-81, 2013

8. Hsu D, Efird J, Hedley Whyte E: Progesterone and estrogen receptors in meningiomas, prognostic considerations. J Neurosurg 86:113 - 120, 1997

9. Ishiwata T, Teduka K, Yamamoto T, Kawahara K, Matsuda Y, Naito Z: Neuroepithelial stem cell marker nestin regulates the migration, invasion and growth of human gliomas. Oncol Rep 26:91-99, 2011

10. Kasuya H, Kubo O, Tanaka M, Amano K, Kato K, Hori T: Clinical and radiological features related to the growth potential of meningioma. Neurosurg Rev 29:293-296, 2006

11. Kitai R, Horita R, Sato $K$, Yoshida K, Arishima H, Higashino Y, Hashimoto N, Takeuchi H, Kubota T, Kikuta K: Nestin expression in astrocytic tumors delineates tumor infiltration. Brain Tumor Pathol 27:17-21, 2010

12. Lakomy R, Sana J, Hankeova $S$, Fadrus $P$, Kren L, Lzicarova E, Svoboda M, Dolezelova H, Smrcka M, Vyzula R, Michalek J, Hajduch M, Slaby O: MiR-195, miR-196b, miR-181c, miR-21 expression levels and 0-6-methylguanine-DNA methyltransferase methylation status are associated with clinical outcome in glioblastoma patients. Cancer Sci 102:2186-2190, 2011

13. Mahmood A, Caccamo DV, Tomecek FJ, Malik GM: Atypical and malignant meningiomas: A clinicopathological review. Neurosurgery 33:955-963, 1993

14. Maier H, Ofner D, Hittmair A, Kitz K, Budka H: Classic, atypical, and anaplastic meningioma: Three histopathological subtypes of clinical relevance. J Neurosurg 77:616-623, 1992

15. Milde T, Hielscher T, Witt H, Kool M, Mack SC, Deubzer HE, Oehme I, Lodrini M, Benner A, Taylor MD, von Deimling A, Kulozik AE, Pfister SM, Witt O, Korshunov A: Nestin expression identifies ependymoma patients with poor outcome. Brain Pathol 22:848-860, 2012 
16. Mirimanoff RO, Dosoretz DE, Linggood RM, Ojemann RG, Martuza RL: Meningioma: Analysis of recurrence and progression following neurosurgical resection. J Neurosurg 62:18-24, 1985

17. Morshead CM, Reynolds BA, Craig CG, McBurney MW, Staines WA, Morassutti D, Weiss S, van der Kooy D: Neural stem cells in the adult mammalian forebrain: $A$ relatively quiescent subpopulation of subependymal cells. Neuron 13:1071-1082, 1994

18. Nakasu S, Hirano A, Shimura T, Llena JF: Incidental meningiomas in autopsy study. Surg Neurol 27:319-322, 1987

19. Niki T, Pekny M, Hellemans K, Bleser PD, Berg KV, Vaeyens $F$, Quartier E, Schuit F, Geerts A: Class VI intermediate filament protein nestin is induced during activation of rat hepatic stellate cells. Hepatology 29:520-527, 1999

20. Shi L, Jiang D, Sun G, Wan Y, Zhang S, Zeng Y, Pan T, Wang Z: miR-335 promotes cell proliferation by directly targeting Rb1 in meningiomas. J Neurooncol 110:155-162, 2012
21. Shibuya $M$, Hoshino $T$, Ito $S$, Wacker MR, Prados MD, Davis $\mathrm{RL}$, Wilson CB: Meningiomas: Clinical implications of a high proliferative potential determined by Bromodeoxyuridine labelling. Neurosurgery 30:494 - 498, 1992

22. Suzuki S, Namiki J, Shibata S, Mastuzaki Y, Okano H: The neural stem/progenitor cell marker nestin is expressed in proliferative endothelial cells, but not in mature vasculature. J Histochem Cytochem 58:721-730, 2010

23. Tyagi A, Chakrabarty A, Franks A: MIB1 proliferation index in meningiomas: Does it predict recurrence? $A$ clinicopathological study. Br J Neurosurgery 18:357-361, 2004

24. Vranic A, Peyre $M$, Kalamarides $M$ : New insights into meningioma: From genetics to trials. Curr Opin Oncol 24: $660-665,2012$

25. Zhi F, Zhou G, Wang S, Shi Y, Peng Y, Shao N, Guan W, Qu H, Zhang Y, Wang Q, Yang C, Wang R, Wu S, Xia X, Yang Y: A microRNA expression signature predicts meningioma recurrence. Int J Cancer 132:128-136, 2013 